\title{
«Loi mongole vs loi islamique. Entre mythe et
} réalité ». Annales. Histoire, Sciences Sociales, vol. 5/6, 2005, pp. 971-996.

\section{Jean Richard}

\section{(2) OpenEdition}

1 Journals

Édition électronique

URL : http://journals.openedition.org/abstractairanica/17292

DOI : 10.4000/abstractairanica.17292

ISSN : 1961-960X

Éditeur :

CNRS (UMR 7528 Mondes iraniens et indiens), Éditions de l'IFRI

\section{Édition imprimée}

Date de publication : 15 mai 2007

ISSN : 0240-8910

\section{Référence électronique}

Jean Richard, « «Loi mongole vs loi islamique. Entre mythe et réalité ». Annales. Histoire, Sciences Sociales, vol. 5/6, 2005, pp. 971-996. », Abstracta Iranica [En ligne], Volume 28 | 2007, document 148 mis en ligne le 18 septembre 2007, consulté le 25 septembre 2020. URL : http:// journals.openedition.org/abstractairanica/17292 ; DOI : https://doi.org/10.4000/abstractairanica. 17292

Ce document a été généré automatiquement le 25 septembre 2020

Tous droits réservés 
«Loi mongole vs loi islamique. Entre mythe et réalité ». Annales. Histoire, Sciences Sociales, vol. 5/6, 2005, pp. 971-996.

\author{
Jean Richard
}

On admet généralement que Gengis-khan promulgua en 1206 un code complet de lois à observer par tous les sujets de l'empire universel auquel il prétendait, le yāsā. D. Aigle montre que cette perspective, retenue par Pétis de la Croix et ses successeurs, procède en fait des historiens musulmans de l'âge mamelouk, tel Maqrīzī, mais est démentie par Juvaynī, plus au contact des réalités mongoles, et par les sources latines et chinoises. À la différence de la charia à laquelle les premiers l'assimilaient, le yasa ne vise qu'à assurer une soumission à l'empire et aux exigences de la souveraineté, notamment en matière militaire, laissant aux peuples leurs coutumes propres sans les assujettir à celles des Mongols. On pourrait se demander si, en tolérant les différents cultes, mais en obligeant les clergés à prier pour le grand khan en retour des privilèges qui leur étaient reconnus, ils ne les soumettaient pas au yāsā tout en respectant leurs propres coutumes.

\title{
INDEX
}

Thèmes : 4.1. Histoire médiévale 
AUTEURS

JEAN RICHARD

Académie des Inscriptions et Belles Lettres 